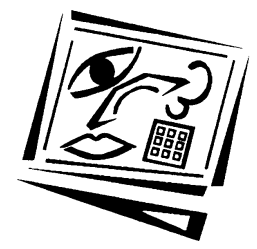

\title{
The intersections of curriculum development: Music, ICT and Australian music education
}

\author{
Jane Southcott and Renée Crawford \\ Monash University
}

\begin{abstract}
Recently, in Australia both the National Review of School Music Education and The Australian Curriculum identify the importance of technology in school music education. However, the understanding of music technology, as demonstrated by state and territory curricular guidelines, is limited with technology mostly recognised as a tool. In comparison, contemporary Australian information and computer technology (ICT) curricula appear to have a very different understanding of how technology can enhance learning in the arts, specifically music. Through a comparison of the Australian States and Territories Years 7-10 curricular guidelines this article compares understandings in the two domains - ICT and the arts (particularly music). The different perspectives on the use of technology in music education can be seen as either using technology as a tool to support instruction in drill-like programs or as a platform for collaborative and creative learning that resonates with students in Australian music classrooms.
\end{abstract}

\section{Introduction}

Since the 1980s all areas in Australian school curricula have been influenced by information and computing technology (ICT), and music has been no exception. In the past twenty years there has been a rapid, almost overwhelming expansion of the use of technology in school music programs. For the purposes of this discussion music technology ranges from notation and recording software to hardware interfaces; electronic keyboards to MIDI interfaces; multi-track recorders to iPods. This rapidly expanding array is increasingly available in school music departments and ICT facilities. Music teachers are often highly motivated to utilise these burgeoning resources, although the rapidity of change can leave teachers floundering. Cartwright and Hammond (2007) acknowledged that, despite the widespread claims concerning the potential benefit of using ICT in education, there has been relatively little impact in school teaching and learning. Encouragingly, there continues to be wide recognition that interaction and cross fertilisation between music and technology can create exciting and engaging teaching and learning opportunities (Moore, 1992; McCoy, 2000; Byrne \& MacDonald, 2002). Swearingen (2002) identified the ubiquitousness of computer technology and that music educators should develop a philosophy to underpin their inclusion of technology in teaching and learning. Continuing this assertion Mark and Madura (2010) argue that "technology will continue to evolve and music teachers will need to be prepared for a shifting paradigm for music education" (p. 140). However, there are concerns about the ways in which technology can be incorporated in school music. These should be carefully considered and teachers should be well-supported to approach the inclusion of ICT. However, too often it appears that busy teachers have little time to engage with what new technologies offer. 
Teachers are well aware that contemporary school students are frequently immersed in music technology and that its presence in a school program can be an attractant. Nearly twenty years ago Moore (1992) argued that "many of our students are greater users of technology outside school than they are during the school day" (p. 43) and it can be suggested that this has not changed. Choi and Piro (2009) concur that, "modern youth are connected to technology like no previous generation" (p. 32). Music educators need to stay abreast of developments in technologies and their use by students. Cain (2004) points out that curricula and classroom practices should "keep pace with the world outside" (p. 219) and that the divide, long recognised by music educators, between their students' experiences of music in the classroom and outside, needs to be closed. Mark and Madura (2010) agree that music teachers need to question the relevance of "their instruction to increasingly technological youth" ( $p$. 140) which, if not addressed, may result in declining enrolments in school music. Teachers, like their students, should consider ICTs as now "commonplace and uncontroversial" (Dillon \& Brown, 2007).

Although a lack of resources may be a realistic issue in many music classrooms (Crawford, 2009b). Byrne explains that, "students are familiar with high quality, sophisticated sounds around them and working with a good quality backing brings a sense of authenticity to the music they are playing in class" (2002, p. 266). Despite the willingness by many music teachers to engage with new technologies, there remains a disjunction between teacher understandings and student expectations. It is reasonable to suggest that music technologies have advanced since many teachers completed their music and music education tertiary courses, and it is also reasonable to argue that many teachers do not have the time to pursue professional development in the use of ICTs in music when there are many matters calling for their attention. Given these constraints, school music educators might look to the curricular guidelines that frame their teaching. As will be discussed, there are different curriculum frameworks in each state and territory in Australia and currently they offer little specific direction for music teachers. This article will explore what guidelines are offered to school music teachers about the role of ICTs in their programs, and contrast this with how curriculum frameworks for ICTs discuss music and the arts. An additional concern is that, at present, Australia is developing its first national curriculum.

In 2009 the Australian Curriculum Assessment and Reporting Authority (ACARA), the statutory body responsible for the development of the national curriculum, announced that literacy, numeracy and information and computing technology (ICT) would underpin the whole curriculum:

\begin{abstract}
Rapid and continuing advances in information and communication technologies (ICT) are changing the ways people share, use, develop and process information and technology, and young people need to be highly skilled in ICT. While schools already employ these technologies in learning, there is a need to increase their effectiveness significantly over the next decade (MCEETYA, 2008).
\end{abstract}

This document does not specifically mention music, rather it refers to the performing and visual arts. The Draft shape of the Australian Curriculum: The Arts includes a general statement about ICT and its role in allowing "students to use new and emerging digital hardware and software in order to create and investigate artworks ... to enhance established conventions, as well as to create new and innovative works" (ACARA, 2010, p. 22). However, in the postulated National Curriculum the federal government has committed to the teaching of the five art forms (dance, drama, media, music, and 
visual arts) and ICT is identified as significant in the teaching of each discipline. The national curriculum is being developed and introduced in three phases. The Arts are mooted for introduction Phase 2 in 2013 (ACARA, 2009). Originally omitted, the inclusion of the Arts has been the result of lobbying but the debate continues about whether they will be mandatory or optional, how many of the arts should be included, and what should be taught in those subjects.

The place of music in the Australian curriculum is an area of concern to many interested persons. This debate seems to replicate a major Australian Government report into school music undertaken five years ago. In 2005 the National Review of School Music Education (NRSME) found that music was poorly resourced, often neglected, and general teachers in primary schools were unprepared to deliver effective, sequential music education (Walker, 2009). The NRSME found that "there is a need for immediate priority on improving and sustaining the quality and status of music education" (DEST, 2005, p. v.). The report also specifically identified the importance of "technology to contemporary music education" (DEST, 2005, p. vix) and the need to improve curriculum support in a number of areas including music technology. This is not a new debate. In 1956 the Melbourne UNESCO Seminar considered just this topic and recommended that schools should have well-equipped music rooms that contained "all the classroom aids necessary for a modern and realistic approach to the teaching of music" which at that time included the new technologies of audio music reproduction and visual projection (Weeden, 1957, p. 13). Although the specifics of the technology may have changed, "the need for a well equipped, dedicated facility for school music has not" (Southcott, 2009, p. 90).

Educators recognise the importance of technology both within their own domains and as a subject in its own right. As stated, technology has been identified as underpinning all learning in the pending Australian national curriculum. This paper will consider the intersections between ICT curricula and music currricula as understood by the various education authorities in the Australian states and territories. There are six states (Queensland, New South Wales, Victoria, Tasmania, South Australia and Western Australia) and two territories (Northern Territory and the Australian Capital Territory). Currently, each state has its own education system and curriculum guidelines. Although this will change with the advent of the national curriculum, the established understandings that underpin current curricula are unlikely to change and present documents will influence future writings. There seems to be a difference in how ICT educators envisage how music is understood in their domain and how music educators see the place of ICT in theirs.

Music education curricula in Australia seem to perceive ICT as offering a different set of tools to support music education, much as a new set of percussion instruments might do. This limited understanding is identified by Mark and Madura (2010) as computer aided instruction (CAI) in which the potential benefits of music technology in teaching are limited to assisting with ear-training, sight singing and notational skills. Crawford (2009a) confirms that, in the United States, "music technology and computer technology in the form of computer-aided instruction (CAI) was frequently used in a highly-structured classroom setting. This learning environment, which used simulated and guided instruction, promoted intensive skill development" (p.154). Adopting a different approach, Mills and Murray (2000) assert that music technology "lessons were good when the pupils worked primarily as musicians" (p. 218). Bray (2000) suggested that ICT has the potential to enhance creativity, facilitate learning, 
encourage exploration and independent learning. This can be identified as computer aided learning (CAL). This approach to using technology in the classroom was first adopted by music teachers in the United Kingdom where they, "supported a curriculum promoting creativity and independent learning. This less skill-intensive approach was considered more suitable for general music classes and encouraged problem solving" (Crawford, 2009a, p. 154). This more real-life or authentic learning is linked by Cain (2004) to advances in technology:

Technological developments have brought with them practical changes in the music curriculum as teachers have incorporated new hardware and software into their teaching. Electronic keyboards and computers have given children a range of sounds that are very similar to the ones heard in popular music, making it possible to relate more closely school music and the world outside (p. 216).

Both CAI and CAL can be identified in Australian state and territory curricula for music and for ICT, although it appears that the proportion of each varies between disciplines. There are both similarities and differences across the curricula for compulsory years of secondary schooling (Years 7 to 10). This can be identified by a set of recurring themes that occur throughout the documents. In this article there will first be a discussion of the ICT curricular statements that mention music and the arts. Second there will be a discussion of the Arts and Music curricular statements concerning the use and role of technology. In this discussion we are focussing on the curricula for Years 7 to 10 for two reasons. First, few primary schools have extensive music technology resources, in fact, many have little music education per se (DEST, 2005) and in secondary schools, Years 7 to 10 are included within the compulsory years of schooling and are not governed by the expectations of the various final years' school curricula.

\section{Methodology}

This research is primarily a document analysis. This qualitative approach studies written sources of data, in this case various curricular statements concerning music and concerning information and communication technology in Australian state and territory education guidelines. There is also a consideration of recent Australian Government pronouncements, particularly those that deal with mooted national curricula. As in all research methods, document analysis has advantages and disadvantages. For example, gathering information is comparatively easy although winnowing kernels of data from lengthy government documents can be a challenge. Further, it must be acknowledged that data gathered from government sources can be biased and can also be more idealistic than practical. Although initially summarising data in tables it soon became clear that the sometimes extensive statements were not easily compressed and a more discursive approach to the data was adopted. Quotations from the relevant documents have been used throughout to illustrate the points made.

\section{Information and communication technology (ICT) curricula: General aims}

ICT is understood to include "digital communications systems, including computers, associated peripheral devices and software, which are commonly linked together in networks" (Education and Training, 2009, p. 43). The pervasive nature of ICT in contemporary society is frequently remarked upon and is seen to be local, national and 
global. For example, the Northern Territory (NT) curriculum states that, "our learners face many complex, diverse and uncertain global and local social, economic, political and environmental issues" in a rapidly changing technological world (Department of Education and Training, 2009b, p. 2). There appear to be five distinct recurring themes in state and territory curriculum documents that describe the expected and required use and role of technology in education primarily for:

1. Communication (local and global)

2. Critical thinking, creativity and problem solving

3. Research

4. Societal context

5. Tool/skill

Understandably, curricular statements concerning ICT generally mention the importance of communication at many levels including peers, teachers, and experts. Such communication is seen to support more than the interchange and accessing of information. It offers the opportunity for students to become "competent, discriminating and creative users of ICT" (New South Wales Government, 2007). With the exception of the NT and Queensland (Q1d), technology for the use of communicating is a priority found in the curriculum documents of all states and territories in Australia. The use of technology as a means of communication is encompassed under overarching statements such as students will "Communicate and interact using ICT with a range of local and global audiences" (Education and Training, 2009, p. 45). The use of technology to enhance critical thinking, creativity and problem solving is found in the curricula of all states and territories except New South Wales (NSW) and the NT. ICT is seen as "a learning tool to support thinking and to analyse and creatively represent new understanding" (Education and Training, 2009, p. 45). According to the Australian Capital Territory (ACT), this will assist students in developing their ability to "present critical opinions and problem solve with others" at Years 9 and 10 level (Education and Training, 2009b, p. 45).

It is reasonable to suggest that using technology as a research tool is a common preconception about the use of ICT, which is probably why it is not actually mentioned in half the curriculum documents. For example, the ACT curriculum explains that students are to, "routinely use ICT to enhance their ability to research and learn through inquiry, with an understanding that using ICT can enable broader inquiry and access to a wider variety of information, opinions and perspectives" (Education and Training, 2009b, p. 45). The use of the word 'routinely' suggests universality. Similarly, the Western Australian (WA) curriculum states that students "have the necessary skills to use technology to analyse and interpret information. This involves them actively exploring innovations such as the Internet, not only as a source of information but also as an opportunity for self expression" (Curriculum Council, 1998, p. 74). Again, the preconception of using technology for researching information is stated as 'necessary', but then the suggestion is made to develop this as a means of engagement through self-expression. The Tasmanian (TAS) curriculum expands the idea of Internet research as an interactive means through the use of portals such as YouTube, seen as a means for both information gathering and self expression (Department of Education, 2008b). In Victoria (Vic), the Victorian Curriculum Assessment Authority (VCAA) (2008a) also continues to support expanding the access of online data beyond routine tasks by using the gathered information to "model and control events" and "construct new understandings" (VCAA, 2008a, p. 97). 
Societal context, a recurring theme throughout six of the state and territory guidelines, excluding NT and South Australia (SA), is also deemed to be important with curricular statements arguing for an understanding of issues that is responsive and equitable. This theme includes the ideas of technology for real life contexts and for the benefit of society in both the short and long term. This idea is developed in the Qld curriculum which states that students "use their understandings of the relationships between technology and society to consider the roles people play in shaping products and processes" (Queensland Studies Authority, 2007a, p. 1). The curriculum further states that this should develop in later years with students adopting a range of perspectives to acquire an understanding of "how information, materials and systems can be combined in innovative ways in response to real-world situations" (Queensland Studies Authority, 2007b, p. 1). In WA the curriculum states that students should also "develop an openness and a capacity to adapt to future technological change" and the skill to "critically appreciate the consequences of technological innovation" (Curriculum Council, 1998, p. 75).

ICT in education is also understood as offering the potential to develop personal learning skills in students, not only in the use of technology but also in the ability to become independent, lifelong learners. For example, in Tas "information rich classrooms .... enable learners to be self-directed and to assume greater control over their learning ... [and] become actively engaged and informed citizens in local and global communities" (Department of Education, 2008b, p. 5). All of the states and territories, except Tasmania, specifically mention the potential of ICT to support interdisciplinary learning, reinforcing the multilinear way in which contemporary adolescents engage with technology. Crawford (2007) explains that the emphasis on technology and its application are a response to societal expectations, requirements, and what it is that is considered valued knowledge, "many music educators are bypassed in our technological society of information superhighways, hypertext media and instantaneous global messaging" (p. 95). While 'Generation $X^{\prime}$ ' is becoming a mere recollection of yesterday, the cultural conditioning and high expectations of what is now termed 'Generation $T x t^{\prime}$ ' is rapidly becoming commonplace in business corporations, and society in general. This terminology 'Generation Txt' also known as 'Generation Text', is used to describe the teens and young professionals who have fuelled the Philippines texting frenzy. It also signifies the powerful convergence of technology, communication and culture (Hilado, 2003). Crawford (2007) explains that:

The requirements of society have radically changed the perception of valued
knowledge. Knowledge valuable to whom and in what context, the questions may be
posed. Perhaps the knowledge itself has not changed and it is merely a case of its
format, transmission and comprehension through current technological
communication. Computer technology and technological advancement has created an
endless array of possibilities for both teaching and learning music. One can already
begin to construct an understanding of how technology... in a non-linear or
multidimensional world, could provide a source of valued knowledge (p. 95).

Thirty years ago Papert (1981) called the computer the "children's machine", because many students grow up in a world of computers. SOCCI (2001) confirm that:

Technology is an integral part of their [students] world, they play, are entertained and learn with the computer and tend to be more visual learners than the previous generations because their world is rich in visual stimuli and they thrive on interacting with the device. The introduction of such technology into the classroom has also the 
potential to extend and amplify the number and kinds of learning experiences provided to students as well as to motivate students (p. 10).

The current generation of children in Australian schools are now referred to as 'digital natives' (Bennett, Maton \& Kervin, 2008).

\section{Information and communication technology (ICT) curricula: The arts including music}

Within ICT curricula across Australia, statements are made that identify how technology supports and interacts with the arts and specifically with music education. For example, in the ACT the curriculum explains that, "by becoming critical and creative users of ICT, students will develop and demonstrate their understandings of concepts and perspectives on issues, topics and ideas presented in the Arts discipline" (Education and Training, 2009b). Although many of the same issues are identified as in the general discussion of ICT, the emphasis is changed. Communication is again stressed, particularly in terms of communicating arts products at local, national and global levels, but communication is extended to include collaboration, for example in Qld, students are expected to use ICTs in "purposeful ways ... to communicate their own arts practice and that of others" (Qld 2007a, p. 1). Similarly, in the ACT students are expected to "communicate and collaborate with others in local and global contexts" (Education and Training, 2009a, p. 43).

The societal and cultural context in which arts are created are noted both as important and as changing. In Qld (2007a, p. 1) students are expected to use their "understandings of the relationships between technology and society to consider the roles people play in shaping products and processes". The arts industries are cited as offering vocational opportunities for artists to "create new arts forms" with emerging ICTs (SACSA, 2008a). A range of specific arts ICT tools and skills are mentioned in several curricula. Understandably, these mainly concern visual arts, media and music. In South Australia (2008b) students are encouraged to develop, produce and present "animation, computer imaging, computer-aided design and digital and electronic recording". These discussions are reiterations and extensions of the general ICT statements. What is interesting is the emphasis given by all ICT curricula to innovation and creativity as it might apply to the arts. All states mention creativity and then tease out the term. Queensland (2007a, p. 1) states that students select and use tools and ICTs "to inquire and solve artistic problems, to create and present arts works". Critical thinking is encouraged in all curricular statements.

The ICT curricular statements concerning the Arts and Music describe technology not only as a useful tool that can improve skills and techniques, but also as a powerful research medium with limitless communication capabilities. Further, music technology can inspire imagination and creativity, and encourage problem solving and critical thinking. It is this level of engagement with learning that is considered as authentic practices that fulfil student and societal expectations. The Victorian Curriculum and Assessment Authority elaborates that this "domain encompasses a range of cognitive affective and metacognitive knowledge skills and behaviours which are essential for effective functioning in society both within and beyond schooling" (VCAA, 2008a, p. 97). It will be interesting to compare such understandings with those identified in the Music curricular statements. 


\section{Music curricula: ICTs}

In the curricular statements for music in the Australian states and territories there are recurring themes in the discussion of technology. Some authorities say very little about technology. For example, there are no specific statements in the ACT curriculum for this area. It is simply implied that technology will be used in music as ICT is regarded as interdisciplinary in the overall curriculum framework. Other states make very broad statements. The Tas music curriculum makes one over-arching pronouncement: "Music is a unique way of organising and making sense of sound. It is an art form that evolves continually being heavily influenced by technological development. Music involves expressing ideas and forms in natural, acoustic and digital environments" (Department of Education, 2008a, p. 119). Similarly, WA only makes a very general comment concerning ICTs and music for Years 7 and 8: "Students are guided to use technologies appropriately and safely and they begin to display and understand values about the use of technology, such as environmental responsibilities" (Curriculum Council, 1998, p. 64). In Year 9 this develops to the consistently vague, "Students increasingly show confidence in using technology" (1998, p. 66) which culminates with, in Year 10, "Young adults should be encouraged to explore emerging technologies...An interest in the technological aspects of the arts... should be fostered without letting technical considerations dominate" (1998, p. 68). Considering the familiarity with which most secondary school students approach technologies, these are little more than stating the obvious.

In the remaining educational authorities similar themes to those of the ICT curricular statements are identified. These again describe the expected and required use and role of technology primarily for:

1. Communication (locally and globally)

2. Critical thinking, creativity and problem solving (including composing)

3. Research

4. Societal context (including the impact of technology on music)

5. Tool/skill (including sound sources)

Communication is only included in music statements in South Australia and Victoria. In South Australia it is identified in Years 7 and 8 by the following statement: "Identify personal and group strengths in order to utilise opportunities for performance/presentation within the community... and/or online/virtual communities" (SACSA, 2008c). Communication appears to be a way to promote or advertise students' artistic work. This also appears in the Year 9 and 10 curriculum framework which states that students should be, "Confidently exploring and using interactive multimedia arts works and emergent online technologies for production and distribution of their work" (SACSA, 2008d). Across the Victorian curriculum it is stated that students should use technology as a means to "communicate ideas" (VCAA, 2008b). The notion of collaboration is not articulated. Crow (2006) explains the collaborative possibilities offered by music technology, where students might make personal musical choices of which a "manifestation of this is the 'playlist' of mp3 files. With free programs such as iTunes and Windows Media Player, pupils can rip, play, order and share their musical choices" (p. 124).

Critical thinking, creativity and problem solving is stated across the curricula of all five states and territories that have not been discounted. The VCAA states that students should: 
Experiment with, select and use appropriate skills, techniques, processes, media, materials, equipment and technologies across a range of art forms and styles. They combine and manipulate arts elements, principles and/or conventions to represent and communicate ideas and develop imaginative solutions to set tasks (VCAA, 2008b, p. 21).

In the Year 9 and 10 Victorian curricular guidelines this is extended:

Students independently and collaboratively, apply their knowledge and understanding to design, create and produce arts works influenced by the style of particular artists and cultures. They effectively use a range of traditional and contemporary media, materials, equipment and technologies (VCAA, 2008b, p. 24).

Similarly, the NT curriculum requires students to be able to "Investigate a range of ... technologies applying these when planning, creating and presenting musical works. The Vic and NT curricula are quite broad in comparison to the NSW statement that gives more specific requirements of technology in music such as, "Experiments with different forms of technology in the composition process (Board of studies, 2003, p. 12).

The use of technology in music for research is only found in SA and Vic guidelines. In the SA document it is stated that students should be, "Accessing libraries and digital and electronic technologies to research connections in traditional art practice" (SACSA, 2008c). More broadly, the VCAA expect that, "Students research, observe and reflect on their explorations to develop, discuss, express and support opinions about their own and others' use of arts elements, principles and/or conventions, skills, techniques processes, media, materials, equipment and technologies" (VCAA, 2008b, p. 21). The reason for the lack of acknowledgement of technology in this area may be because it has been covered in more general parts of the framework and is therefore an interdisciplinary requirement. However, it is interesting to note the lack of detail included by the music curriculum writers. The fact that it is not included can create the misconception that it is not required or expected in the discipline of music per se.

In the music curricular frameworks societal context concerning technology in music is addressed by most states and territories (except Qld, Tas and WA). In the case of Qld this omission is surprising considering the strength of their statements concerning society in the ICT curricular guidelines, where quite strong links are made between societal context and the use and impact of technology in education. The Victorian curriculum implies that societal context is related to the understanding of how artists and cultures can influence music and the related technologies that are used to create and re-create art works (VCAA, 2008b). The NSW curriculum states that in Years 7 and 8 students will develop understanding and be able to identify the use of technology appropriate to a certain musical context. However, by Years 9 and 10, this understanding is extended to societal context in, "Demonstrating an understanding of the influence and impact of technology on music" (Board of Studies, 2003, p. 13). Similarly, the NT curriculum states that students should be able to, "Identify the impact of digital technology on contemporary composition and performance" (Department of Education and Training, 2009, p. 460). South Australia states that students, "Select appropriately and use new technologies, seeing them as belonging to their current and future worlds... Recognising how emerging technologies can both increase access and influence the development of arts forms and the nature of arts works" (SACSA, 2008c). It can be argued that all themes so far identified are based on societal expectations and requirements. 
The use of technology in music as a tool/skill (including that of a sound source) appears consistently and most strongly in all five states and territories relevant to this area. This again highlights the importance of technology in music practice. The SA curriculum summarises this appropriately for Years 7 and 8 students, as being able to "use technologies as arts learning and production environments in the creation of arts works e.g. musical speakers and immersive environments" (SACSA, 2008c). This is further clarified for Years 9 and 10 students as being able to "control the tools and technologies of arts practice, such as sound and lighting desks, computer-aided design software and hardware; and control their own technical skill in the playing of a musical instrument" (SACSA, 2008d). There is a clear recognition of the importance of ICT in contemporary music practices. In NSW it is asserted in the curriculum that:

Musicians are avid consumers of new technologies. Advances during the twentieth and twenty-first centuries have influenced and will continue to influence the ways in which musicians work, both in terms of the instrument they play and the means by which they record and share performances (Board of Studies, 2003, p. 19).

It can be argued that musicians have always made use of technological advances and contemporary understandings are no different. Technology as a tool and as a skill consistently appear in the curricula of every state and territory in Australia, with the exception of Northern Territory where there is no statement in this area. For example, in NSW:

Ongoing developments in analog and digital electronics have meant that musicians have access to a wide range of new instruments and sounds as well as the means to record and manipulate sounds. Synthesisers, sequencers, non-linear recording and editing systems are everyday tools of many musicians (Board of Studies, 2003, p. 19).

This statement reflects an understanding of the creative and critical potential of ICTs in music and the arts, that resonates with how artists and musicians engage with their art forms. Thus technology is seen here as reflecting authentic practices in the arts. While the tools and skills described in the curricula of this area are not as in depth as the previous section, they still imply the same thing. Students are to use technology to develop their skills by exploring various hardware and software applications. The key here is the suggestion that this is what artists are using and doing in their practice. Once again, although not as strong, there is the suggestion that curricula are relating to societal context through encouraging real life artistic practices in educational situations. In the area of technology in music, the music curriculum writers and music educators are not as convincing in their delivery, which suggests a misconception about the expectations and requirements of ICT in music education. While this disparity exists there is still the recognition that technology is a useful tool and may encourage new thinking processes through critical evaluation and creativity.

\section{Discussion and conclusion}

There is a disparity between how writers of ICT curricula in Australia see the arts and music and how the writers of music curricula understand the role and use of ICT. Phelps and Maddison (2008) found a similar situation in their consideration of the use of ICT in visual arts, stating that, "while some teachers have embraced new technologies, many continue to use ICT in a limited manner" (p. 1). It appears that, in some cases, music educators too have yet to embrace the totality of what ICT can offer. There is a difference between CAI in which ICT supports the development of skills in 
music and CAL which, as Choi and Piro (2009) explain, encompasses digitally based instruction in the arts which includes state of the art technology, that should support the advancement of free and creative expression and reflection. Mark and Madura (2010) point out that, "music education is likely to change dramatically with the use of emerging technologies" (p. 140). It appears that many of the reasons for using technology in education, both conceptual and practical, are derived by societal expectations and requirements. It is these values that govern what is deemed important in education and in turn what appears in our curriculum documents. It is interesting that the ICT educators seem to have a better idea of the learning that can be achieved and enhanced by using technology in the Arts and Music.

Ruthmann (2007) asks the pertinent question whether music instruction in the digital age should focus on traditional music CAI or should it explore CAL possibilities such as sound manipulation using new technologies. As the emphasis on authentic, student centred learning increases, technology will continue to advance and music educators must be ready to accommodate changing paradigms for school music. This is evident as the distinction between CAI and CAL has become less apparent, "CAI is now considered a knowledge-based approach that uses technology for role-playing and simulated learning. Creativity and composition still appear to motivate CAL. Teachers everywhere are using technology that combines strengths of each approach" (Crawford, 2009a, p. 157). However, while there are obvious benefits to using technology for teaching and learning there is a lack of theoretical frameworks and curriculum models that are current and address technological issues. Teachers need to be given access to practical models that will assist them to use technology effectively in their own practice. This will need to begin with a re-evaluation of terminology, definitions and discourses used to discuss music education. Teresa Dillon (2007) points out that the dearth of understanding that exists concerning creative and collaborative possibilities of music technology affects "the training of teachers, the design of music technologies and the development of meaningful music activities" (p. 118).

This is certainly evident in comparing the understandings of the role of technology in music and the arts from the different perspectives of the curriculum writers from the two domains. It is clear that the music educators and music curriculum writers are not as open to the learning potential or possibilities that can be achieved by technology. Their focus for technology is primarily as a tool rather than a medium for musical thought and expression. Curriculum should be "concerned with the use of IT ... to enhance students' attainment in music, rather than the use of music to develop students' IT capability" (Mills, 1997, p. 109). Cain (2004) also observed that some teachers may "embrace ICT wholeheartedly, sometimes to the exclusion of singing and playing acoustic instruments ... [while] others virtually ignore it" (p. 218). He suggests that this may not be wholly a question of financial resources but may rather be based on the teacher's valuing of music technology. Cain argues that an "adequate, overarching theory of music education that takes account of new technologies could help to locate music technology within the curriculum as a whole" (p. 218). Such theoretical frameworks for new music curricula should address contemporary expectations. Cain (2004) also stated that, "curriculum change is necessary if the world of the classroom is to keep pace with the world outside. And it is also necessary to have clearly defined theory which allows teachers to commit themselves intellectually to the change" (p. 219). Crow (2006) argues that teachers have:

not yet grasped the role that the new technology might play in developing authentic and relevant approaches while broadening access. Their own perceptions make it 
difficult for them to recognise or value such approaches... Hence music teachers need to rethink, redesign, develop and resource a 'new' music curriculum (p. 126).

Such a reassessment might go some way to addressing the assumptions that underpin curricular statements that see ICTs in music education as a tool and may also begin to address the disregard held by some pupils for school music.

At present it appears that ICT curriculum writers have a more sophisticated understanding of just what can be done with technology and it is important that music educators consider what is being offered. As Cain (2004) points out, dialogue is:

essential, especially between teachers who use technology a lot and those who use it reluctantly. ICT enthusiasts need to understand that those who are reluctant to use music technology might not be technophobes; they might have genuine and principled concerns, perhaps relating to certain less musical aspects of technology (p. 220).

These less musical aspects are those that see music technologies as providing another tool in CAI, such as those identified by Mark and Madura (2010) as including programs that support notational skill, aural training, and sight reading although these authors also mention programs that support improvisation and composition. Dillon and Brown (2007) see such programs as increasing "access to authentic musical experiences". It is important that music educators make the time to explore the possibilities of both CAI and CAL in their use of ICTs. Speaking of art education, Mayo (2007) concurs that "art educators as teachers, artists and researchers have an opportunity to utilize this new landscape of digital technology to develop the artistresearchers of tomorrow" (p. 50).

Music educators should also be judicious in their choices of which technologies to include. Selwyn (2002) points that, not all technological developments have enhanced teaching and learning over the past two decades. Technologies should be chosen that enhance students' musical creativity. Teresa Dillon (2007) considers it important that technologies should not just be parachuted into "school situations without understanding" (p. 125) and for this reason we need to explore individual and collaborative processes, consider teaching and learning, remain aware of advancements in technologies, learn from our mistakes, and work authentically as musicians and educators. Way and Webb (2007) also found that the integration of ICT into all aspects of school curricula could be challenging for Australian schools as they try to align policy directives, curricular statements, and individual school agendas. As part of this process, music educators should collaborate with their colleagues in ICTs who appear, from the current curricular statements, to hold a broader and more imaginative understanding of the potential roles and practices of music technology in schooling.

\section{References}

Australian Curriculum, Assessment and Reporting Authority (ACARA) (2010a). Australian Curriculum Phase 2. http: / / www.acara.edu.au/acara_update_30032010.html [viewed 18 April 2010, verified 10 Jan 2011].

Australian Curriculum, Assessment and Reporting Authority (ACARA) (2010b). Draft shape of the Australian Curriculum: The Arts. [viewed 10 Jan 2011]. http: / www.acara.edu.au/verve/ _resources/Draft+Shape+Of+The+Australian+Curriculum+The+Arts-FINAL.pdf 
Bennett, S., Maton, K. \& Kervin, L. (2008). The 'digital natives' debate: A critical review of the evidence. British Journal of Educational Technology, 39(5), 775-786.

Board of Studies, New South Wales (2003). Music Years 7-10 Syllabus. [viewed 21 Apr 2009]. http: / / www.boardofstudies.nsw.edu.au/syllabus_sc/pdf_doc/music_710_syllabus.pdf

Byrne, C. \& Macdonald, R. A. R. (2002). The use of information and communication technology (I\&CT) in the Scottish Music Curriculum: A focus group investigation of themes and issues. Music Education Research, 4(2), 263-273.

Cain, T. (2004). Theory, technology and the music curriculum. British Journal of Music Education, $21(2), 215-221$.

Cartwright, V. \& Hammond, M. (2007). 'Fitting it in': A study exploring ICT use in a UK primary school. Australasian Journal of Education Technology, 23(3), 390-407. http: / / www.ascilite.org.au/ajet/ajet23/cartwright.html

Choi, H. \& Piro, J. (2009). Expanding arts education in a digital age. Arts Education Policy Review, $110(3), 27-33$.

Crawford, R. (2007). Authentic learning and digital technology in the music classroom. Victoria: Monash University [Unpublished PhD dissertation]

Crawford, R. (2009a). An Australian perspective: Technology in secondary school music. Journal of Historical Research in Music Education, 30(2), 147-167. http: / / www.highbeam.com/doc/1G1-204853985.html

Crawford, R. (2009b). Secondary school music education: A case study in adapting to ICT resource limitations. Australasian Journal of Educational Technology, 25(4), 471-488. http: / / ascilite.org.au/ajet/ajet25/crawford.html

Crow, B. (2006). Musical creativity and the new technology. Music Education Research, 8(1), 121-130.

Curriculum Council, Western Australia (1998). Curriculum Framework for Kindergarten to Year 12 Education in Western Australia. http: / / www.curriculum.wa.edu.au/pages / framework/ framework04.htm [viewed 18 Nov 2008; not found 10 Jan 2011, see current version at http:/ / www.curriculum.wa.edu.au/internet/Years_K10/Curriculum_Framework]

Department of Education, Tasmania (2008a). The Tasmanian Curriculum - Arts Curriculum Area K10 syllabus and support materials. [viewed 11 Nov 2008, verified 10 Jan 2011]. http: / / resources.education.tas.gov.au/item/edres/1e956148-5841-2dba-ef9d1e03185e9025/1/ syl-arts-all.pdf

Department of Education, Tasmania (2008b). The Tasmanian Curriculum - Information and Communication Technologies (ICT) K-10 Cross Curricular Framework and support materials. [viewed 24 Apr 2009, verified 10 Jan 2011]. http:/ / resources.education.tas.gov.au/ item/edres/ded5a485-71df-b37f-be86-24e85e9621db/1/syll-ict-all.pdf

Department of Education and Training, Northern Territory (2009). Northern Territory Curriculum Framework: Arts Learning Area. http:/ / www.det.nt.gov.au/education/teaching_and_learning/curriculum/ ntcf/ docs/learning_areas_arts.pdf [viewed 24 Apr 2009, not found 10 Jan 2011, see item dated 2002 at http: / / www.det.nt.gov.au /__data/assets / pdf_file/0013/2371/ learning_ areas_arts.pdf]

Dillon, S. C. \& Brown, A. R. (2007). Realising the possibilities of technology in music education research and philosophy. In Proceedings Fifth International Research in Music Education Conference, Exeter, UK. [viewed 24 April 2009, verified 10 Jan 2011]. http: / / eprints.qut.edu.au/13214/1/13214.pdf

Dillon, T. (2007). Current and future practices: Embedding collaborative music technologies in English secondary schools. In J. Finney \& P. Burnard (Eds.), Music education with digital technology, 117-127, London: Continuum. 
Education and Training, Australian Capital Territory (2009a). Every chance to learn: Curriculum framework for ACT schools. Early adolescence. [viewed 10 May 2009, verified 10 Jan 2011]. http: / / activated.act.edu.au/ectl/ resources/ECTL_EarlyAdolescence.pdf

Education and Training, Australian Capital Territory (2009b). Every chance to learn: Curriculum framework for ACT schools. Later adolescence. [viewed 10 May 2009, verified 10 Jan 2011]. http: / / activated.act.edu.au/ectl/ resources/ECTL_LaterAdolescence.pdf

Hilado, J. K. F. (2003). Generation text. The GUIDON, 27 February. [viewed 24 Aug 2004, not found 10 Jan 2011]. http: / / www.theguidon.com/ default.php?get=2003020403

Johansen, G. (2009). An education politics of the particular: Promises and opportunities for the quality of higher music education. Arts Education Policy Review, 110(4), 33-37.

Mark, M. \& Madura, P. (2010). Music education in your hands. New York: Routledge.

Mayo, S. (2007). Implications for art education in the third millennium: Art technology integration. Art Education, 60(3), 45-51.

McCoy, P. (2000). Digital technologies in the music classroom. In E. Pontiff (Ed.), Spotlight on technology in the music classroom, 110-112, Reston, VA: MENC.

Ministerial Council on Education, Employment, Training and Youth Affairs (MCEETYA) (2008). Melbourne declaration on educational goals for young Australians. [viewed 12 April 2010, verified 10 Jan 2011]. http: / / www.mceecdya.edu.au/mceecdya/melbourne_declaration,25979.html

Moore, B. (1992). Music, technology, and an evolving curriculum. NASSP Bulletin, 76, 42-46.

Papert, S. (1981). Mindstorms: Children, computers, and powerful ideas. USA: Basic Books.

Pascoe, R., Leong, S., MacCallum, J., Mackinlay, E., Marsh, K., Smith, B., Church, T. \& Winterton, A. (2005). National review of school music education: Augmenting the diminished. Department of Education, Science and Training. [verified 10 Jan 2011; 3.0 MB] http: / / www.dest.gov.au/NR/rdonlyres/C9AFAE54-6D72-44CC-A3463CAF235CB268/8944/music_review_reportfinal.pdf

Phelps, R. \& Maddison, C. (2008). ICT in the secondary visual arts classroom: A study of teachers' values, attitudes and beliefs. Australasian Journal of Educational Technology, 24(1), 114. http: / / www.ascilite.org.au/ajet/ajet24/phelps.html

Queensland Studies Authority (2007a). Technology: Essential learnings by the end of Year 7. [viewed 22 Apr 2009, verified 10 Jan 2011].

http:/ / www.qsa.qld.edu.au/downloads/early_middle/qcar_el_technology_yr7.pdf

Queensland Studies Authority (2007b). Technology Essential Learnings by the end of Year 9. [viewed 22 April 2009, verified 10 Jan 2011].

http:/ / www.qsa.qld.edu.au/downloads / early_middle/qcar_el_technology_yr9.pdf

Ruthmann, S. A. (2007). Strategies for supporting music learning through on-line collaborative technologies. In J. Finney \& P. Burnard (Eds.), Music education with digital technology, 131-141, London: Continuum.

South Australia Curriculum Standards Authority (SACSA) (2008a). South Australian Curriculum Standards and Accountability Framework: Middle Years 6-9: Arts: Introduction. [viewed 11 November 2008]. http: / / www.sacsa.sa.edu.au/index_fsrc.asp? $t=C B \& I D=B 3.1 A$

South Australia Curriculum Standards Authority (SACSA) (2008b). South Australian Curriculum Standards and Accountability Framework: Middle Years 6-9: Arts: Literacy, numeracy and information and communication technologies in the arts. [viewed 11 Nov 2008, verified 10 Jan 2011]. http: / / www.sacsa.sa.edu.au / index_fsrc.asp?t=CB\&ID=B3.1A 
South Australian Curriculum Standards Authority (SACSA) (2008c). South Australian Curriculum Standards and Accountability Framework: Middle Years 6-9: Arts: Arts practice. [viewed 11 Nov 2008, verified 10 Jan 2011]. http: / / www.sacsa.sa.edu.au/index_fsrc.asp?t=CB\&ID=B3.1A

South Australian Curriculum Standards Authority (SACSA) (2008d). South Australian Curriculum Standards and Accountability Framework: Senior Years 10-12: Arts: Arts practice. [viewed 11 Nov 2008, verified 10 Jan 2011]. http: / / www.sacsa.sa.edu.au /index_fsrc.asp?t=CB\&ID=B3.1A

Selwyn, N. (2002). Telling tales on technology: Qualitative studies of technology and education. Aldershot: Ashgate.

SOCCI (Schools Online Curriculum Content Initiative, The Le@rning Federation) (2001). Market Research Report, October 2001. Faculty of Education, Queensland University of Technology, Brisbane. [viewed 12 Jul 2005, not found 10 Jan 2011]. http: / / www.thelearningfederation .edu.au/tlf2 / sitefiles/images / brochures/background / market_research/mkt_ch2.pdf

Southcott, J. E. (2009). The Melbourne UNESCO Seminar, 1956: A watershed in Australian music education. In M. Comte (Ed.), Musical dimensions: A Festschrift for Doreen Bridges, 80-98. Australia: Australian Scholarly Publishing.

Swearingen, K. D. (2001). A philosophy and strategies for technology in music education. In E. Pontiff (Ed.), Spotlight on technology in the music classroom, 114-116, Reston, VA: MENC.

VCAA (Victorian Curriculum and Assessment Authority) (2008a). Interdisciplinary learning. In Victorian essential learning standards: Level 6, pp. 98-120. [viewed 22 Apr 2009, verified 10 Jan 2011]. http:/ / vels.vcaa.vic.edu.au/downloads/vels_standards/velsrevlvl6.pdf

VCAA (Victorian Curriculum and Assessment Authority) (2008b). Discipline-based learning: The Arts. In Victorian essential learning standards: Level 6. [viewed 22 Apr 2009, verified 10 Jan 2010]. http: / / vels.vcaa.vic.edu.au/downloads/vels_standards/velsrevlvl6.pdf

Walker, R. (2009). Beethoven or Britney? The great divide in music education. Platform Papers, (20). [viewed 10 Jan 2011; excerpt only].

http:/ / www.currencyhouse.org.au/pages/pp_issue_20.html

Way, J. \& Webb, C. (2007). A framework for analysing ICT adoption in Australian primary schools. Australasian Journal of Educational Technology, 23(4), 559-582.

http: / / www.ascilite.org.au/ajet/ajet23/way.html

Weeden, W. J. (1957). Foreword. In Music in education: Report of the Australian Unesco Seminar held in Melbourne, May-June, 1956. Australian National Advisory Committee for Unesco.

Dr Jane Southcott, Faculty of Education, Monash University

Clayton Campus, Wellington Road, Clayton Victoria 3800, Australia

Email: Jane.Southcott@monash.edu

Web: http: / / www.education.monash.edu.au/profiles/jsouth

Dr Renée Crawford, Faculty of Education, Monash University

Clayton Campus, Wellington Road, Clayton Victoria 3800, Australia

Email: crawfy12@aol.com

Please cite as: Southcott, J. \& Crawford, R. (2011). The intersections of curriculum development: Music, ICT and Australian music education. Australasian Journal of Educational Technology, 27(1), 122-136.

http: / / www.ascilite.org.au/ajet/ ajet27 / southcott.html 